\title{
Peningkatan Keterampilan Menulis Teks Pidato Dengan Model Pembelajaran Cooperative Group Investigation Pada Siswa Kelas XA SMA Negeri 1 Samalantan
}

\author{
Ertin Dwi Septaviani ${ }^{1)}$ Zulfahita $^{2)}$ \\ IProgram Studi Pendidikan Bahasa dan Sastra Indonesia STKIP Singkawang \\ email:dwiseptavianiertin@gmail.com \\ 2Program Studi Pendidikan Bahasa dan Sastra Indonesia STKIP Singkawang \\ email:Zulfahita@yahoo.com
}

\begin{abstract}
Abstrak. Penelitian ini didasari oleh rendahnya kemampuan siswa dalam kegiatan pembelajaran menulis. Hal tersebut disebabkan kurangnya minat siswa dalam menulis. Penelitian ini difokuskan pada materi menulis teks pidato dengan model cooperative group investigation. Rumusan masalah yang terdapat pada penelitian ini adalah bagaimanakah perencanaan, bagaimanakah pelaksanaan, dan bagaimanakah hasil dari kegiatan pembelajaran menulis teks pidato dengan model cooperative group investigation. Metode yang digunakan dalam rencana penelitian ini adalah metode deskriptif. Deskriptif artinya data terurai dalam bentuk kata-kata atau gambar-gambar bukan dalam bentuk angka-angka [8]. Metode ini digunakan untuk mengetahui tentang peningkatan keterampilan menulis teks pidato dengan model pembelajaran Cooperative Group Investigation pada siswa kelas X A SMA Negeri 1 Samalantan. Bentuk penelitian ini adalah kualitatif dan kuantitatif. Menurut McMilan Schumacher dalam [4] "Kualitatif adalah suatu pendekatan yang juga disebut pendekatan investigasi, karena biasanya peneliti mengumpulkan data dengan cara bertatap muka langsung dan berinteraksi dengan orang-orang di tempat penelitian". Penelitian ini dilaksanakan dengan 2 siklus, setiap siklus 2 kali pertemuan. Prosedur dalam penelitian ini terdiri atas perencanaan, tindakan, pengamatan, dan refleksi hasil kegiatan pembelajaran. Perencanaan pembelajaran siklus 1 terdiri atas merumuskan tujuan pembelajaran, menentukan model pembelajaran, memilih materi, menyusun Rencana Pelaksanaan Pembelajaran, serta pedoman penilaian. Perencanaan pada siklus 2 sama dengan siklus 1, tetapi lebih ditekankan pada pemahaman terhadap materi dan penerapan model pembelajaran cooperative group investigation. Pelaksanaan pembelajaran disesuaikan dengan perencanaan yang telah disusun. Pelaksanaan siklus 1 memiliki kendala pada kesiapan siswa, kesiapan kelas, pemilihan tema, serta pemberian motvasi. Pelaksanaan siklus 2 berjalan dengan baik, semua aspek dalam perencanaan sudah silaksanakan oleh guru. Berdasarkan analisis data pada Penelitian Tindakan Kelas ini, sebelum adanya tindakan nilai rata-rata siswa 68,2\%. Setelah tindakan siklus 1 adanya peningkatan menjadi 70,25\%, dan meningkat lagi pada siklus 2 menjadi 79,48\%. Berdasarkan penelitian ini, disarankan agar guru dapat menerapkan model pembelajaran cooperative group investigation untuk meningkatkan kemampuan menulis siswa.
\end{abstract}

Kata kunci : Menulis, Cooperative Group Investigation, Teks Pidato.

\section{PENDAHULUAN}

Bahasa Indonesia memiliki empat aspek keterampilan berbahasa yaitu menyimak, berbicara, membaca dan menulis [1]. Keempat aspek tersebut sangat berpengaruh dalam proses pembelajaran bahasa Indonesia. Berbahasa dalam ragam tulis tidak hanya mewujudkan perasaan dan pikiran ke dalam bentuk tulisan, melainkan juga didasarkan pada pengetahuan serta pengalaman individu. Tingkat keberhasilan seseorang dalam hal penguasaan bahasa dapat dilihat melalui lisan dan tulisan. Keterampilan menulis di antaranya adalah menulis teks pidato. "Pidato adalah penyampaian gagasan, pikiran atau informasi serta tujuan dari pembicara kepada orang lain (audience) dengan cara lisan [3]". Sebelum melisankan pidato, peserta didik terlebih dahulu membuat teks pidato.

Pada Kurikulum Tingkat Satuan Pendidikan ini terdapat pelajaran bahasa Indonesia dengan materi menulis teks pidato yakni dalam silabus dengan Standar Kompetensi Menulis 12. Mengungkapkan informasi melalui penulisan paragraf dan teks pidato dengan Kompetensi Dasar 12.4.Menyusun teks pidato. Banyak hal yang perlu diperhatikan dalam menulis teks pidato mulai dari pembuka, isi, dan penutup. Mengingat pentingnya keterampilan menulis teks pidato yang baik dan benar bagi perkembangan ilmu pengetahuan serta membentuk jiwa kepemimpinan siswa, peneliti ingin berkolaborasi dengan guru bahasa Indonesia di SMA Negeri 1 Samalantan, Lailil Mahfudloh, S.Pd. Alasan penulis memilih SMA Negeri 1 Samalantan adalah untuk membantu siswa di SMA Negeri 1 Samalantan 
dalam melakukan kegiatan menulis, khususnya menulis pidato. Penelitian tentang menulis teks pidato juga belum pernah dilakukan di sekolah tersebut.

Selain itu, guru cenderung melakukan kegiatan pembelajaran satu arah dan belum menerapkan model pembelajaran yang sesuai dengan materi serta karakteristik siswa. Konvensional merupakan kegiatan pembelajaran sederhana yang umumnya terpusat kepada guru. Pembelajaran konvensional pada umumnya tidak/ kurang memperhatikan ketuntasan belajar, khususnya ketuntasan siswa [5]. Masalah dalam penelitian ini adalah "Bagaimanakah peningkatan keterampilanmenulis teks pidato dengan model pembelajaran Cooperative Group Investigation pada siswa kelas X A SMA Negeri 1 Samalantan?" submasalah yang dapat dirumuskan dalam penelitian ini adalah bagaimanakah perencanaan, pelaksanaan dan hasil dalam kegiatan pembelajaran menulis menulis teks pidato dengan model pembelajaran Cooperative Group Investigation pada siswa kelas X A SMA Negeri 1 Samalantan.

Penelitian ini dilakukan dengan tujuan yang berdampak pada peningkatan kegiatan belajar siswa. Secara umum penelitian ini bertujuan untuk mendeskripsikan peningkatan kemampuan menulis teks pidato dengan model pembelajaran Cooperative Group Investigation pada siswa kelas X A SMA Negeri 1 Samalantan. Sedangkan tujuan khusus dalam penelitian ini adalah untuk mendeskripsikan perencanaan, pelaksanaan, dan hasil dari kegiatan pembelajaran menulis teks pidato dengan model pembelajaran Cooperative Group Investigation pada siswa kelas X A SMA Negeri 1 Samalantan.

\section{METODE}

Metode yang digunakan dalam rencana penelitian ini adalah metode deskriptif. Deskriptif artinya data terurai dalam bentuk kata-kata atau gambar-gambar bukan dalam bentuk angka-angka [8]. Metode ini digunkan untuk memberikan gambaran yang jelas dan rinci mengenai data atau fakta yang terjadi di lapangan selama proses penelitian berlangsung. Metode ini digunakan untuk mengetahui tentang peningkatan kemampuan menulis teks pidato dengan model pembelajaran Cooperative Group Investigation pada siswa kelas X A SMA Negeri 1 Samalantan.

Bentuk penelitian ini adalah kualitatif dan kuantitatif. Data Kuantitatif adalah data yang berbentuk angka atau data kualitatif yang diangkakan [10]. Sedangkan kualitatif menurut McMilan Schumacher dalam [4] "Kualitatif adalah suatu pendekatan yang juga disebut pendekatan investigasi, karena biasanya peneliti mengumpulkan data dengan cara bertatap muka langsung dan berinteraksi dengan orang-orang di tempat penelitian".

Rancangan penelitian ini dilakukan dalam bentuk Penelitian Tindakan Kelas (PTK). Penelitian Tindakan Kelas (PTK) adalah suatu kegiatan penelitian ilmiah yang dilakukan secara rasional, sistematis dan empiris reflektif terhadap berbagai tindakan yang dilakukan oleh guru atau dosen (tenaga pendidik), kolaborasi (tim peneliti) yang sekaligus sebagai peneliti, sejak disusunnya suatu perencanaan sampai penilaian terhadap tindakan nyata di dalam kelas yang berupa kegiatan belajar-mengajar, untuk memperbaiki dan meningkatkan kondisi pembelajaran yang dilakukan [9]. Penelitian ini dilakukan dengan cara berkolaborasi bersama guru mata pelajaran bahasa Indonesia di SMA Negeri 1 Samalantan, Lailil Mahudloh, S.Pd., dalam penelitian ini peneliti bertindak sebagai pengamat. Penelitian tindakan ini dilakukan dengan sekurang-kurangnya dua siklus, setiap siklus dilaksanakan dengan empat tahap yaitu perencanaan tindakan, pelaksanaan tindakan, pengamatan tindakan dan refleksi tindakan. Rencana penelitian ini dibatasi dengan materi menulis teks pidato dengan menggunakan bahasa yang mudah dipahami.

Teknik dan alat pengumpul data merupakan bagian penting dalam penelitian yang digunakan sebagai pedoman mengenai bagaimana cara penulis mengumpulkan data serta alat yang digunakan dalam mengumpulkan data tersebut.

1. Teknik Pengumpul Data

Teknik pengumpulan data dalam penelitian ini adalah sebagai berikut:

a. Teknik Evaluasi/ Tes

Instrumen yang berupa tes ini dapat digunakan untuk mengukur kemampuan dasar dan pencapaian atau prestasi [2]. Dalam kegiatan ini penulis menggunakan tes esay yang dilakukan disetiap akhir tindakan. Tes berupa soal latihan yang berkaitan dengan materi pidato dilakukan untuk mengetahuan tingkat pemahaman siswa terhadap materi tersebut.

b. Observasi

Observasi adalah alat pengumpulan data yang digunakan dalam penelitian menggunakan teknik observasi secara langsung [10]. Lembar observasi yang digunakan dalam penelitian ini adalah APKG 1 untuk menilai kegiatan guru dalam merencanakan bahan ajar, APKG 2 untuk menilai guru dalam kegiatan pelaksanaan pembelajaran, dan lembar pengamatan sikap siswa selama kegiatan belajarmengajar berlangsung.

2. Alat Pengumpul Data

Alat pengumpul data dalam penelitian ini berupa tes dan lembar observasi sebagai berikut:

a. Tes menggunakan soal esay untuk mengukur tingkat pemahaman siswa terhadap materi menulis teks pidato.

b. Lembar observasi dalam proses pembelajaran menulis teks pidato menggunakan Cooperative Group Investigation adalah sebagai berikut:

1) Alat Penilaian Kemampuan Guru (APKG 1) dalam merencanakan pelaskanaan pebelajaran menulis teks pidato dengan model Cooperative Group Investigation.

2) Alat Penilaian Kemampuan Guru (APKG 2) dalam melaksanakan kegiatan pembelajaran menulis teks pidato dengan model Cooperative Group Investigation.

3) Lembar pengamatan sikap siswa dalam pelaksanaan pembelajaran menulis teks pidato dengan model Cooperative Group Investigation. 
Pelaksanaan Penelitian Tindakan Kelas (PTK), terdapat dua jenis data yang penulis kumpulkan, yaitu:

a. Teknik Statistik Deskriptif Komparatif

Teknik statistik deskriptif komparatif digunakan untuk menghitung data kuantitatif yang bersifat tes yaitu dengan membandingkan hasil antar siklus. Data diperoleh dari nilai tes hasil belajar siswa dalam menulis teks pidato menggunakan model Cooperative Group Investigation. Di dalam teknik ini ditampilkan nilai antarsiklus maupun dengan indikator kinerja, sehingga akan tampak kemajuan yang diperoleh siswa pada setiap siklusnya.

1) Merekap skor yang diperoleh siswa

2) Menghitung skor komulatif dari seluruh aspek

3) Menghitung skor rata-rata

4) Menghitung persentase dengan rumus.

Rumus penilaian rata-rata:

Nilai $=\underline{\text { Skor yang diperoleh }} \times$ skala

[7] Skor maksimum

TABEL 1

Kriteria Penilaian

\begin{tabular}{|c|c|c|l|}
\hline $\begin{array}{c}\text { Interval } \\
\text { persentase tingkat } \\
\text { penguasaan }\end{array}$ & \multicolumn{2}{|c|}{ Nilai skala lima } & \multicolumn{1}{|c|}{ Keterangan } \\
\cline { 2 - 3 } & $1-4$ & D- A & \\
\hline $86-100$ & 4 & A & Baik Sekali \\
$76-85$ & 3 & B & Baik \\
$56-75$ & 2 & C & Cukup \\
$10-55$ & 1 & D & Kurang \\
& & & \\
\hline
\end{tabular}

[6]

b. Teknik Analisis Kritis

Teknik analisis kritis digunakan untuk menghitung data kualitatif. Data kualitatif digunakan untuk menghitung data yang bersifat nontes berupa lembar observasi. Informasi deskripsi yang dianalisis berkaitan tentang motivasi belajar siswa, tingkat pemahaman siswa terhadap pembelajaran, pandangan siswa, teman sejawat terhadap materi, metode, media, evaluasi yang digunakan dalam proses pembelajaran menulis teks pidato. Perencanaan pelaksanaan pembelajaran dianalisis menggunakan format APKG 1 untuk mengetahui kemampuan guru menyusun RPP menulis teks pidato. Pelaksanaan pembelajaran dianalisis menggunakan APKG 2untuk mengetahui kemampuan guru melaksanakan pembelajaran menulis teks pidato. Sikap siswa selama proses pembelajaran dianalisis menggunakan format penilaian sikap.

\section{HASIL DAN PEMBAHASAN}

HASIL
Setelah melakukan dua siklus Penelitian Tindakan Kelas yang dilakukan peneliti dan kolaborator Lailil Mahfudloh, S.Pd terhadap keterampilan siswa dalam menulis teks pidato dengan model pembelajaran Cooperative Group Investigation siswa kelas X A SMA Negeri 1 Samalantandiperoleh peningkatan hasil disetiap siklusya dengan perbandingan sebagai berikut.

\section{Perencanaan Pembelajaran Menulis Teks Pidato dengan Model Cooperative Group Investigation Siklus 1 dan 2}

Perencanaan pembelajaran yang telah disusun dari siklus 1 dan siklus 2 mengalami peningkatan. Perencanaan pembelajaran yang dibuat telah sesuai dengan kriteria penilaian. Kegiatan perencanaan pembelajaran menulis teks pidato dengan model cooperative group investigation pada siklus 1 mencapai $82,81 \%$ dan siklus 2 mencapai $98,4 \%$, dengan demikian dapat dikatakan bahwa perencanaan pembelajaran mengalami peningkatan yaitu $15,59 \%$. Berdasarkan hasil peningkatan perencanaan tersebut maka hasil pembelajaran juga akan meningkat menjadi lebih baik.

2. Pelaksanaan Pembelajaran Menulis Teks Pidato dengan Model Cooperative Group Investigation Siklus 1 dan 2

Kegiatan pelaksanaan pembelajaran menulis teks pidato menggunakan model Cooperative Group Investigation setiap siklusnya mengalami peningkatan. Siklus 1 dan 2 pertemuan pertama meningkat $20,8 \%$ sedangkan pertemuan kedua meningkat $15,3 \%$. Disimpulkan bahwa kategori pencapaian pelaksanaan pembelajaran meningkat menjadi baik sekali. Pelaksanaan pembelajaran menulis teks pidato menggunakan model Cooperative Group Investigation mengalami peningkatan. Pelaksanaan pembelajaran dilakukan dengan sangat baik oleh guru bahasa Indonesia. Dampaknya bagi siswa adalah kemudahan dalam memahami materi sekaligus meningkatkan hasil kerja siswa.

3. Hasil Menulis Teks Pidato dengan Model Cooperative Group Investigation Siklus 1 dan 2

Hasil kerja dapat menentukan tingkat kemampuan siswa dalam menyelesaikan sebuah tugas. Nilai rata-rata siswa pada hasil kerja menulis teks pidato dengan model Cooperative Group Investigation dapat ditingkatkan. Pada siklus 1 rata-rata siswa mencapai 70,25 dengan persentase ketuntasan $71,79 \%$, dan pada siklus 2 mencapai 79,48 dengan persentase ketuntasan mencapai $87,17 \%$. Dapat dikatakan bahwa nilai rata-rata siswa siklus 1 dan 2 mengalami peningkatan sebesar 9,23\%, dan persentase peningkatan keberhasilan siswa mencapai $15,38 \%$.

4. Penilaian Sikap Siswa pada Pembelajaran Menulis Teks Pidato dengan Model Cooperative Group Investigation Siklus 1 dan 2 
Pengamatan terhadap sikap siswa selama kegiatan pembelajaran menulis teks pidato dengan model Cooperative Group Investigation mengalami peningkatan disetiap siklusnya. Penilaian untuk siklus 1 pada aspek berkelompok dengan persentasi baik sekali mencapai 7,6\%, baik 89,74\%, dan cukup 2,56\%. Aspek berdiskusi dengan persentase baik sekali $0 \%$, baik $20,51 \%$, dan cukup $79,48 \%$, serta pada aspek melaksanakan investigasi persentase baik sekali mencapai $2,56 \%$, baik $82,05 \%$, dan cukup $15,38 \%$. Penilaian siklus 2 untuk aspek berkelompok dengan persentase baik sekali $76,92 \%$, baik $20,51 \%$, dan cukup mencapai 2,56\%, aspek berdiskusi dengan persentase baik sekali $61,53 \%$, baik 38,46\%, serta aspek melaksanakan investigasi dengan persentase baik sekali $71,79 \%$, dan baik $28,20 \%$.

Penilaian sikap selama kegiatan pembelajaran menulis teks pidato dengan model Cooperative Group Investigation di kelas X A SMA Negeri 1 Samalantan mengalami peningkatan disetiap siklusnya. Persentase siswa baik sekali dalam kegiatan pembelajaran siklus 1 7,6\% dan meningkat pada siklus 2 menjadi 70,08\%, persentase baik pada siklus $189,74 \%$ dan menurun pada siklus 2 menjadi $29,05 \%$, serta pada persentase cukup juga sama pada siklus $12,56 \%$ sedangkan siklus 2 $2,56 \%$. Berdasarkan penjelasan tersebut maka dapat dikatakan bahwa pada siklus 2 siswa lebih antusias dan lebih banyak siswa aktif dalam kegiatan pembelajaran dibandingkan dengan siklus 1 .

\section{SIMPULAN DAN SARAN}

\section{SIMPULAN}

Berdasarkan hasil penelitian yang dilakukan di kelas X A SMA Negeri 1 Samalantan berkaitan dengan kemampuan siswa dalam menulis teks pidato, maka dapat disimpulkan hal-hal sebagai berikut:

1. Perencanaan pembelajaran menulis teks pidato dengan model Cooperative Group Investigation direncanakan siklus 1 dan 2 masing-masing dua kali pertemuan dengan alokasi waktu $2 \times 45$ menit. Rencana pelaksanaan pembelajaran pada siklus 1 mencapai kriteria baik, meskipun pada aspek pengembangan materi, guru kurang mengembangkan materi yang hendak disampaikan sehingga siswa sulit memahami maksud pembelajaran tersebut. Perencanaan pembelajaran siklus 2 dilakukan perbaikan pada aspek penentuan materi, pengembangan materi, serta penggunaan media. Perbaikan dilakukan dengan menambah materi yang hendak diajarkan sehingga siswa dapat lebih mengetahui maksud dan tujuan yang hendak dicapai. Penentuan tema yang sesuai dengan karakteristik siswa juga dilakukan sebagai upaya mempermudah siswa dalam mengembangkan idenya, kemudian media yang digunakan bertambah sesuai dengan jumlah siswa yang ada bukan berdasarkan kelompok, sehingga semua siswa dapat menyimak proses pembelajaran dengan baik.

2. Peningkatan kegiatan pembelajaran dari siklus 1 dan siklus 2 mengalami peningkatan. Kegiatan pembelajaran menulis teks pidato dilaksanakan dengan langkahlangkah model Cooperative Group Investigation sehingga menjadikan siswa lebih aktif dalam mengikuti kegiatan belajar-mengajar, guru yang memberikan materi juga dapat mengembangkan kreatifitasnya dalam mengajar. Pelaksanaan pembelajaran siklus 1 secara keseluruhan sudah masuk dalam kategori baik, kemudian meningkat pada siklus 2 menjadi baik sekali.

3. Hasil pembelajaran menulis teks pidato dengan model Cooperative Group Investigation meningkat disetiap siklusnya. Hasil pada siklus 1 jumlah siswa tuntas mencapai 28 orang $(71,79 \%)$ dan siswa tidak tuntas 11 orang $(28,20 \%)$. Hasil siklus 2 , jumlah siswa yang tuntas mencapai 34 siswa $(87,17 \%)$ dan siswa tidak tuntas mencapai 5 orang $(12,82 \%)$. Sikap siswa selama kegiatan pembelajaran juga mengalami peningkatan. Persentase siswa baik sekali dalam kegiatan pembelajaran siklus 1 $7,6 \%$ dan meningkat pada siklus 2 menjadi 70,08\%, persentase siswa baik pada siklus $189,74 \%$ dan menurun pada siklus 2 menjadi $29,05 \%$, serta pada persentase cukup juga sama pada siklus $12,56 \%$ dan siklus 2 $2,56 \%$. Berdasarkan penjelasan tersebut maka dapat dikatakan bahwa pada siklus 2 siswa lebih antusias dan lebih banyak siswa aktif dalam kegiatan pembelajaran dibandingkan dengan siklus 1 .

SARAN

Berdasarkan penjelasan di atas, maka peneliti bermaksud mengemukakan pendapat sebagai berikut.

1. Guru mata pelajaran Bahasa Indonesia dapat menggunakan model pembelajaran Cooperative Group Investigation dalam upaya meningkatkan kemampuan siswa dalam kegiatan menulis teks pidato. Guru terlebih dahulu menyusun rencana pembelajaran yang di dalamnya terdapat langkah-langkah kegiatan pembelajaran Cooperative Group Investigation, serta mengikuti langkah-langkah kegiatan tersebut.

2. Sebaiknya siswa dapat bekerja sama dalam proses pelaksanaan kegiatan pembelajaran dengan model Cooperative Group Investigation agar prestasi belajar mereka dapat meningkat serta melatih kemampuan mereka dalam kegiatan menulis.

\section{DAFTAR PUSTAKA}

[1] Aminudin. 2009. Kreatif Membuat Ragam Tulis. Bandung: PT. Puri Pustaka.

[2] Arikunto, Suharsimi. 2006. Prosedur Penelitian Suatu Pendekatan Praktik. Jakarta: PT. Asdi Mahasatya.

[3] Badudu, Rendra dan Dewi Shinta. 2013. 9 Tahap Mempersiapkan Pidato dan MC. Yogyakarta: Pustaka Cerdas.

[4] Damayanti S, Vismaya dan Syamsudin. 2006. Metode Penelitian Bahasa. Bandung: PT. Remaja Rosdakarya.

[5] Majid, Abdul. 2014. Strategi Pembelajaran. Bandung: PT. Remaja Rosdakarya.

[6] Nurgiyantoro, Burhan. 1987. Penilaian dalam Pengajaran Bahasa dan Sastra. Yogyakarta: BPFE. 
Jurnal Pendidikan Bahasa dan Sastra Indonesia

Volume 1 Nomor 1 Maret 2016. Page 1-5

p-ISSN: 2477-5932 e-ISSN: 2477-846X

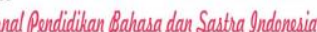

[7] Purwanto. 2014. Evaluasi Hasil Belajar. Yogyakarta: Pustaka Belajar.

[8] Semi, M. Atar. 2012. Metode Penelitian Sastra. Bandung: CV. Angkasa.

[9] Yudhistira, Dadang. 2013. Menulis Penelitian Tindakan Kelas Yang APIK. Jakarta: PT. Gramedia Widiasarana Indonesia.

[10] Zuldafrial. 2012. Strategi Belajar Mengajar. Surakarta: Cakrawala Media 